\title{
Congenital Contractural Arachnodactyly; two unrelated newborns with novel clinical findings
}

\author{
İbrahim Akalın ${ }^{1,2}$, Didem Armangil ${ }^{3}$, Esad Köklü³
}

\begin{abstract}
'Trabzon Women's and Children's Hospital, Genetic Diseases Diagnosis Center, Trabzon, Turkey.
\end{abstract}

${ }^{2}$ Istanbul Medeniyet University, Goztepe Training \& Research Hospital, Medical Genetics. İstanbul, Turkey

3Trabzon Women's and Children's Hospital, Neonatalogy Unit, Trabzon, Turkey.

Eur J Basic Med Sci 2012;2(2):50-55

Received: 24.04.2012

Accepted: 25.04.2012

Correspondence (Yazıșma Adresi): Assist. Prof. Dr. Ibrahim Akalin, MD. İstanbul Medeniyet Üniversitesi, Göztepe Eğitim ve Araștırma Hastanesi Tibbi Genetik Anabilim Dalı 34730, İstanbul, Turkey. Tel: +902165664000 / 9613

Fax: +902165664023

E-mail: ibrahimakalin@yahoo.com

\begin{abstract}
Congenital Contractural Arachnodactyly (CCA; Beals syndrome) is a rare autosomal dominant disorder of connective tissue. CCA represents similar phenotypical features of Marfan syndrome such as tall stature and arachnodactyly, with contrasting multiple joint contractures involving elbows, knees and even fingers with typical crumpled ear helices. Here, we present two separate newborns representing novel findings such as retinal hemorrhage, bilateral simian lines and cryptorchism in addition to classical findings. However, pedigree analyses of patients were suggesting somatic mosaicism in addition to the represented distinct features of Beals syndrome; one with milder phenotype and even lack of typical crumpled ear helices, and the other with severe vertebral findings such as kyphoscoliosis.
\end{abstract}

Key words: Beals syndrome, Marfan syndrome, arachnodactyly, retinal hemorrhage, kyphoscoliosis

Konjenital Kontraktürel Araknodaktili; yeni klinik bulgular içeren iki farklı yenidoğan olgu

\section{ÖZET}

Congenital Contractural Arachnodactyly (CCA; Beals syndrome) otozomal resesif geçişli nadir bir bağ doku hastalığıdır. CCA, uzun boy ve araknodaktili gibi Marfan sendromundakine benzer klinik özellikler ile farklı olarak dirsek, diz ve hatta parmakları içeren çoklu eklem kontraktürleri ile tipik burușuk kulak kepçesi görünümü sergiler. Biz bu yazımızda klasik bulgularına ek olarak retinal kanama, bilateral simian çizgiler ve kriptorșizm bulguları olan iki akraba olmayan yenidoğanı sunmaktayız. Ancak, hastaların pedigri analizleri, Beals sendromunun farklı bulgularına ek olarak somatik mozaikliği de desteklemekle olup, biri hafif fenotipte ve tipik kulak kıvrımlarının yokluğu ile seyrederken diğeri kifoskolyoz gibi ağır vertebral bulgular ile seyretmektedir.

Anahtar Kelimeler: Beals sendromu, Marfan sendromu, araknodaktili, retinal kanama, kifoskolyoz 


\section{INTRODUCTION}

Congenital contractural arachnodactyly (CCA; Beals syndrome, OMIM 121050) is a rare autosomal dominant disorder of connective tissue that represents similar phenotypical features of Marfan syndrome (MFS, OMIM 154700) such as Marfan-like tall and slender appearance with long and slender finger and toes, the-so-called arachnodactyly (1). Since the clinical findings are "gold standard" to put the diagnosis of both MFS and Beals Syndrome, the latter however has been separated from MFS each by clinical and molecular genetic findings (2-4). MFS is caused by a mutation of Fibrilin-1 (FBN1) gene which is located on chromosome 15q15-21.3 (5), whereas Fibrillin-2 (FBN2) is the only gene known to be associated with CCA located on chromosome 5q23-q31 (6). Here, we present two unrelated cases of newborn having discrete and novel findings in the wide clinical spectrum of Beals Syndrome.

\section{CASE REPORT}

\section{Case 1}

The index patient was a full term female infant born to 5 th degree consanguineous healthy parents (the mother and father were 35 and 36 years old, respectively) after an uneventful gestation. The patient was born in Trabzon Women's and Children's Hospital and referred to Medical Genetics Unit with multiple congenital ab-

Tablo 1. Summarized physical examination findings of Case 1 and Case 2. Comparison of clinical findings of cases both with Beals Syndrome and Marfan Syndrome.

\begin{tabular}{|c|c|c|c|c|c|c|}
\hline \multicolumn{3}{|l|}{ Clinical Feature } & \multirow{2}{*}{ Case 1} & \multirow{2}{*}{$\frac{\text { Case } 2}{t^{*}}$} & \multirow{2}{*}{$\frac{\text { Beals Syndrome }}{+}$} & \multirow{2}{*}{$\frac{\text { Marfan Syndrome }}{+}$} \\
\hline Inheritance & - & Autosomal dominant & & & & \\
\hline Growth & Other & Marfanoid habitus & + & + & + & + \\
\hline \multirow[t]{12}{*}{ Head and neck } & Head & Scaphocephaly & + & - & + & + \\
\hline & & Brachycephaly & - & + & + & - \\
\hline & & Dolichocephaly & + & - & + & + \\
\hline & Face & Micrognathia & + & + & $+(27 \%)$ & + \\
\hline & & Frontal bossing & + & - & + & - \\
\hline & Ears & Crumpled ear helices & + & ++ & $++(76 \%)$ & - \\
\hline & & Poorly defined conchae & + & + & + & - \\
\hline & Eyes & Ectopia lentis & - & - & - & + \\
\hline & & Myopia & & & + & + \\
\hline & & Retinal Hemorrhage & $+/+! !$ & - & $?$ & $?$ \\
\hline & Mouth & High-arched palate & + & + & $+(28 \%)$ & + \\
\hline & Neck & Relatively short neck & + & + & + & - \\
\hline \multirow[t]{7}{*}{ Cardio-vascular } & Heart & Mitral valve prolapse & - & - & + & + \\
\hline & & Mitral regurgitation & - & - & + & + \\
\hline & & Atrial septal defect & - & - & + & - \\
\hline & & Ventricular septal defect & - & - & + & - \\
\hline & & Bicuspid aortic valve & - & - & + & - \\
\hline & Vascular & Patent ductus arteriosus & + & - & + & - \\
\hline & & Aortic root dilatation & - & - & + & + \\
\hline \multirow{11}{*}{$\begin{array}{ll}\text { Chest } & \text { Ribs, } \\
\text { Skeletal } & \end{array}$} & um, clavicles, and scapulae & Pectus carinatum & - & + & + & + \\
\hline & & Arachnodactyly & ++ & ++ & $++(86 \%)$ & + \\
\hline & Long & narrow legs and arms & + & + & $+(32 \%)$ & + \\
\hline & & Tall Stature & + & + & + & + \\
\hline & Multiple joint contracture & $26 \%$, elbows $86 \%$, knees $81 \%)$ & ++ & ++ & ++ & - \\
\hline & & Contractural improvement & + & + & $+(\% 88)$ & - \\
\hline & & Kyphosis/scoliosis & - & + & $+(45 \%)$ & + \\
\hline & & Camptodactyly & + & + & $+(78 \%)$ & + \\
\hline & & Club foot deformity & - & + & $+(28 \%)$ & + \\
\hline & & Osteopenia & $?$ & $?$ & + & $?$ \\
\hline & & Simian Line & $+/+! !$ & - & - & - \\
\hline Muscle - & & Muscle hypoplasia & $?$ & $?$ & $+(65 \%)$ & + \\
\hline Neurologic & Central nervous system & Motor developmental delay & $?$ & $?$ & + & - \\
\hline Miscellaneous & & Cryptorchism & - & $+! !$ & $?$ & $?$ \\
\hline Molecular basis & - & Caused by mutations in & $?$ & $?$ & $\begin{array}{l}\text { fibrillin } 2 \\
\text { gene (FBN2, } \\
121050.0001 \text { ) }\end{array}$ & $\begin{array}{l}\text { fibrillin } 1 \\
\text { gene } \\
\text { (FBN1 1) }\end{array}$ \\
\hline
\end{tabular}

* Decided after pedigree analyses.

!! Novel clinical findings within Beals syndrome described firstly by this report. 


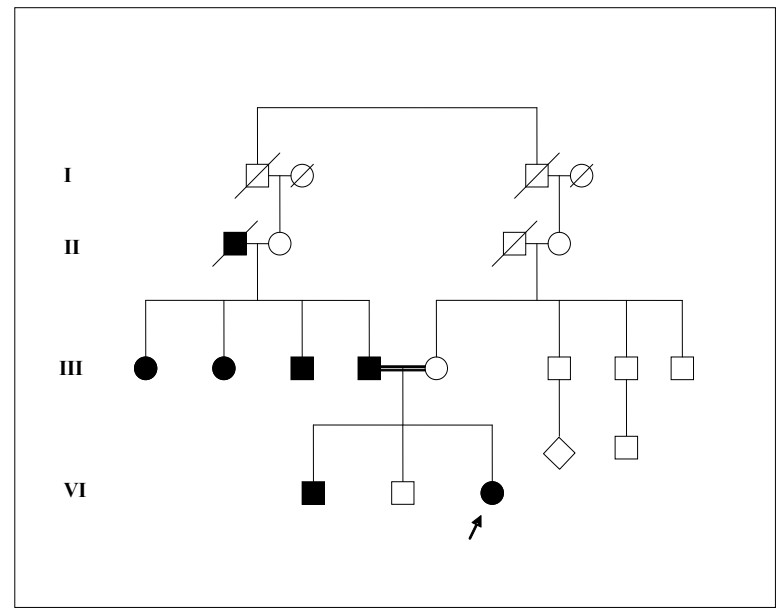

Figure 1. Pedigree of Case 1.

normalities and distinctive arachnodactyly (Pics. 1-2). She was diagnosed as Beals Syndrome with further multiple joint contractures. She was $2600 \mathrm{~g}$ by weight (2550 percentiles), $49 \mathrm{~cm}$ in length ( $75-90$ percentiles) and had a head circumferences of $33 \mathrm{~cm}$ (25-50 percentiles) at birth. Her Apgar score was 7 at 5 th minute. Her physical examination findings were summarized at Table 1. She had low set ears (Pic. 1), hypertelorism and narrow palpebral fissures (Pic. 2). Bilateral retinal hemorrhage has been identified in ophthalmologic examination of the patient. The pedigree revealed long hand and foot at her elder brother, parents, aunts and uncle (Fig. 1).

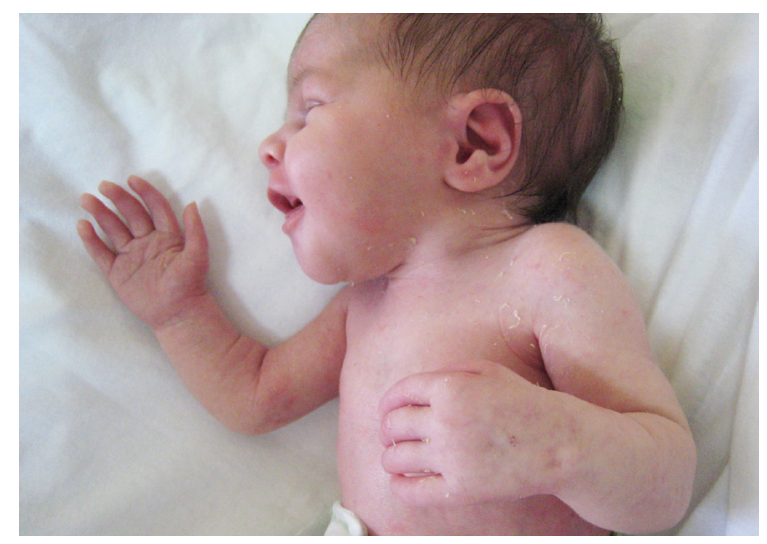

Picture 1: Lateral aspect of the Case 1 showing arachnodactyly, Simian line, short neck, low set ears with normal pinnea.

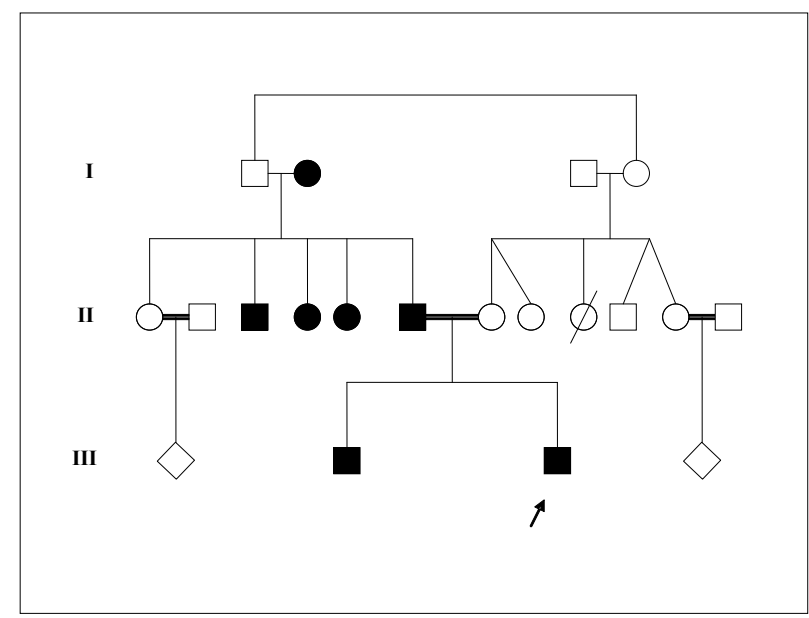

Figure 2. Pedigree of Case 2.

\section{Case 2}

The index patient was a full term male infant born to 3 rd degree consanguineous healthy parents (the mother and father were 29 and 36 years old, respectively) after an uneventful gestation. The patient was born in Trabzon Women's and Children's Hospital and referred to Medical Genetics Unit with multiple congenital abnormalities and distinctive arachnodactyly (Pic. 3). He was first misdiagnosed as neonatal Marfan syndrome, but his diagnosis was corrected as Beals syndrome with multiple joint contractures and crumpled ear abnormality (Pic. 3). He was $3050 \mathrm{~g}$ in weight (50-75 percentiles)

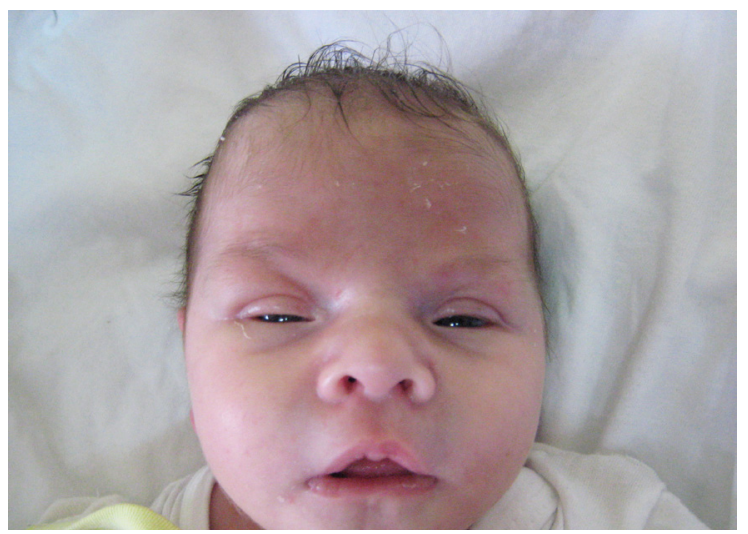

Picture 2: Front view of the Case 1 showing hypertelorism and narrow palpebral fissures. 


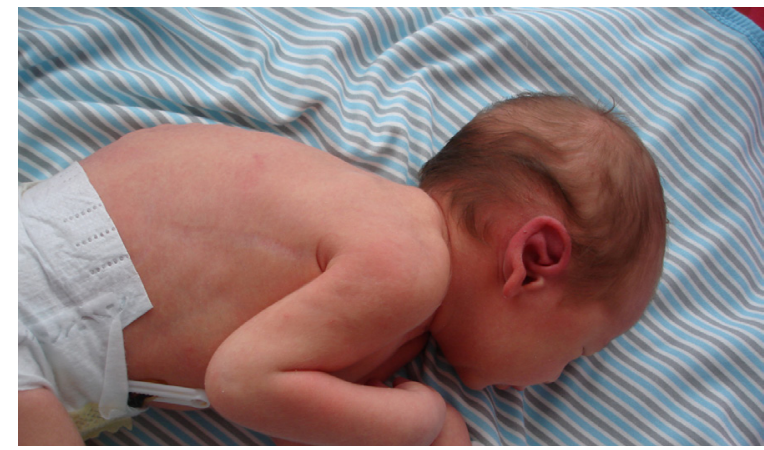

Picture 3: Lateral view of Case 2 showing kyphoscoliosis and contractures at elbow and arachnodactyly.arachnodactyly.

and $50 \mathrm{~cm}$ in length (75-90 percentiles) at birth. His Apgar score was 7 at 5 th minute. The physical examination findings were summarized at Table 1. Bilateral cryptorchism has been identified as a novel finding in Beals Syndrome. The pedigree revealed a long hand and foot at his elder brother, aunts, uncle and grandmother (Fig. 2). His father had long foot only, but an abnormal pinnea. His elder brother also revealed abnormal pinnea. Improvements of joint contractures were noticed at his two months of follow up.

\section{DISCUSSION}

TThe diagnosis of Congenital ContracturalArachnodactyly has put to both newborn patients according to main characteristic manifestations of the syndrome that are arachnodactyly, multiple joint contractures involving elbows, knees and hips, and crumpled ear helices $(1,7)$, especially present at Case 2. However, our patients were representing distinct phenotype in the broad spectrum of the disease, with novel clinical findings such as retinal hemorrhage, cryptorchism, and bilateral simian lines.

In addition to the contracture of major joints especially on elbows and knees, both patients represented flexion contraction of the interphalangeal joints of the fingers and overriding toes (camptodactyly) further with talipes equinevarus deformity in Case 1 and club food deformity in Case 2 (Pic. 4). The latter finding was expected to be seen in $28 \%$ of CCA patients (7). The talipes equinevarus could be considered as a flexion-contraction deformity.

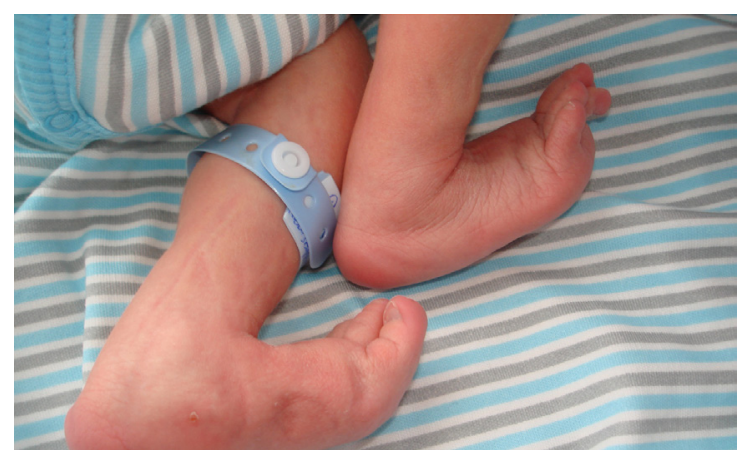

Picture 4: Club food deformity in Case 2.

The spectrum of the CCA varies between the classical findings of the disease, such as marfanoid habitus (tall stature) arachnodactyly, joint contractures, crumpled ears and even less common craniofacial abnormalities (micrognatia, high arched palate and scaphocephaly), and further cardiovascular and gastrointestinal anomalies (2). Since, Wang et al. has attributed the cardiovascular and gastrointestinal anomalies to severe/lethal form of CCA (8), one of our patient represented patent ductus arteriosis in her echocardiographic examination besides typical findings. The observed percentage of the cardiovascular findings and comparison with Marfan syndrome were summarized in Table 1.

Similarly, Case 2 has also mild to moderate kyphoscoliosis (9) (Pic. 3) that has been ascribed as infrequent (46\%) (7) but the most serious complication of the disease in a recent review by Tuncbilek and Alanay (10). In view of the fact that most patients with Marfan syndrome (MFS) do not have abnormally shaped ears, it is reported in some patients with neonatal Marfan syndrome (11). Furthermore, similarities between the neonatal Marfan syndrome and severe lethal CCA include kyphosis/scoliosis and joint contractures as well as arachnodactyly and severe cardiovascular abnormalities (OMIM, \#121050). In case 2, we have had moderate kyphoscoliosis, arachnodactyly (Pic. 3) and joint contractures whereas absence of cardiovascular findings except patent ductus arteriosis. Since it has prognostic significance to put the correct diagnosis, Case 2 was diagnosed as CCA rather than neonatal Marfan syndrome due to the absence of severe cardiovascular findings prone to lethal CCA $(12,13)$ or neonatal MFS $(14,15)$. Unlike to the literature, PDA was 
not accomplished with other cardiovascular abnormalities in our patient $(8,13,16,17)$. Moreover, Case 1 did not also represent abnormal pinnea. Though crumpled pinnea is an important diagnostic finding, it has seen only in $76 \%$ of the CCA cases (7) that makes it highly sensitive diagnostic tool but not a must.

In addition to classical findings of the CCA, Case 1 represented bilateral retinal hemorrhage and bilateral simian lines as novel findings. The ophthalmologic findings were rare in CCA and included heterotopias, ectopia lentis, blue sclera, glaucomatous optic disc cupping, partial coloboma of the lens, mild cataract, abnormal cilliary body and glaucoma $(18,19)$. This was the first case in the literature that report bilateral retinal hemorrhage in CCA syndrome and hence, it is critical to do an ophthalmologic examination in patients with CCA disease. Correspondingly, Case 2 represented bilateral cryptorchism beside severe skeletal findings especially the spinal deformity; kyphoscoliosis. As it is expected in CCA, joint contractures of Case 2 improved at his second month of control examination. In order to explore what makes the peracute phenotypic difference within our patients, the molecular diagnosis was essential. Unfortunately, we were unavailable to set the molecular diagnosis of the patients.

Furthermore, each patient's pedigree revealed mild phenotypic findings in an autosomal dominant manner (Fig. 1 and 2). Long hand and foot were present within sibling, one of parent and aunts/uncles of Case 1 but they were lack of ear abnormalities (Fig. 1). The latter, on the other hand, was present within the father of Case 2 nearby long foot but not long hands (Fig 2). Mother was normal for both hands and foots as well as ears. Those findings revealed an anticipation and full penetration of the disease that were crucial for an autosomal dominant behavior. On the other hand, each patient could remind us the possibility of somatic mosaicism (10) leading to a milder phenotype in the parent with typical features of CCA in the offspring. Both cases and particularly the Case 2 has revealed severe clinical findings whereas the other offspring and the parent did not. This finding suggests both parental somatic and even germ-line mosaicism (4). Therefore, it's critical to identify the mutations in fibrillin-2 gene to understand the genotype/phenotype correlation that underlie the etiology of clinical variations of CCA and hence the accurate genetic counseling.
Consequently, in this report, we described two separate CCA newborn patients with discrete phenotype and novel clinical findings for the first time such as retinal hemorrhage, simian line in hand and cryptorchism. The phenotypic difference between parent and the offspring suggests the clues of somatic mosaicism in CCA.

\section{REFERENCES}

1. Beals RK, Hecht F. Congenital contractural arachnodactyly. A heritable disorder of connective tissue. J Bone Joint Surg Am 1971; 53(5): 987-93.

2. Godfrey M. Fibrillin-2 mutations in congenital contractural arachnodactyly. Robinson PN, Godfrey M, editors. New York: Plenum. 2004; 123-9 p.

3. Hecht F, Beals RK. "New" syndrome of congenital contractural arachnodactyly originally described by Marfan in 1896. Pediatrics 1972; 49(4):574-9.

4. Putnam EA, Park ES, Aalfs CM, Hennekam RC, Milewicz $D M$. Parental somatic and germ-line mosaicism for a FBN2 mutation and analysis of FBN2 transcript levels in dermal fibroblasts. Am J Hum Genet 1997; 60(4): 818-27.

5. Dietz HC, Cutting GR, Pyeritz RE, et al. Marfan syndrome caused by a recurrent de novo missense mutation in the fibrillin gene. Nature 1991; 352(6333): 337-9.

6. Lee B, Godfrey M, Vitale E, et al. Linkage of Marfan syndrome and a phenotypically related disorder to two different fibrillin genes. Nature 1991; 352(6333): 330-4.

7. Viljoen D. Congenital contractural arachnodactyly (Beals syndrome). J Med Genet 1994; 31(8): 640-3.

8. Wang M, Clericuzio CL, Godfrey M. Familial occurrence of typical and severe lethal congenital contractural arachnodactyly caused by missplicing of exon 34 of fibrillin-2. Am J Hum Genet 1996; 59(5): 1027-34.

9. Shikata J, Yamamuro T, Mikawa Y, lida H, Nishimura N. Kyphoscoliosis in congenital contractural arachnodactyly. A case report. Spine (Phila Pa 1976) 1987; 12(10): 1055-8.

10. Tuncbilek E, Alanay $Y$. Congenital contractural arachnodactyly (Beals syndrome). Orphanet J Rare Dis 2006;1: 20.

11. Godfrey M, Raghunath M, Cisler J, et al. Abnormal morphology of fibrillin microfibrils in fibroblast cultures from patients with neonatal Marfan syndrome. Am J Pathol 1995; 146(6): 1414-21.

12. Anderson RA, Koch S, Camerini-Otero RD. Cardiovascular findings in congenital contractural arachnodactyly: report of an affected kindred. Am J Med Genet 1984; 18(2): 265-71.

13. Currarino G, Friedman JM. A severe form of congenital contractural arachnodactyly in two newborn infants. Am $J$ Med Genet 1986; 25(4): 763-73.

14. Geva T, Sanders SP, Diogenes MS, Rockenmacher S, Van Praagh R. Two-dimensional and Doppler echocardiographic and pathologic characteristics of the infantile Marfan syndrome. Am J Cardiol 1990; 65(18): 1230-7. 
15. Gross DM, Robinson LK, Smith LT, Glass N, Rosenberg $H$, Duvic M. Severe perinatal Marfan syndrome. Pediatrics 1989; 84(1): 83-9.

16. Lipson EH, Viseskul C, Herrmann J. The clinical spectrum of congenital contractural arachnodactyly. A case with congenital heart disease. Z Kinderheilkd 1974; 118(1): 1-8.

17. Macnab AJ, D'Orsogna L, Cole DE, Baguley PE, Adderley $R J$, Patterson MW. Cardiac anomalies complicating congenital contractural arachnodactyly. Arch Dis Child 1991; 66(10): 1143-6.
18. Bawle E, Quigg MH. Ectopia lentis and aortic root dilatation in congenital contractural arachnodactyly. Am J Med Genet 1992; 42(1): 19-21.

19. Takaesu-Miyagi S, Sakai H, Shiroma T, Hayakawa K, Funakoshi Y, Sawaguchi S. Ocular findings of Beals syndrome. Jpn J Ophthalmol 2004; 48(5): 470-4. 